B I O S C I E N C E

J O U R N A L

\title{
EFFECTS OF Stryphnodendron adstringens EXTRACTS ON MURINE 4T1 TUMOR LINE
}

\begin{abstract}
Alessandra Aparecida de Melo SOUZA ${ }^{1}$ iD, Elias Raad GERVÁSIO ${ }^{2}$ iD), Thais Barbosa DE PAULA² iD, Luis Ribeiro da SILVA NETO² (D), Fernanda Pinheiro Chagas FERNANDES² iD, Gabriel Furtado LEITE ${ }^{\text {(D) }}$, Felipe Peres BARRETO ${ }^{2}$, Rosy lara Maciel de Azambuja RIBEIRO² iD
\end{abstract}

\footnotetext{
${ }^{1}$ Department of Biochemistry, Federal University of São João del-Rei, Divinópolis, Minas Gerais, Brazil.

2 Department of Medicine, Federal University of São João del-Rei, Divinópolis, Minas Gerais, Brazil.
}

\author{
Corresponding author: \\ Rosy lara Maciel de Azambuja Ribeiro \\ Email: rosy@ufsj.edu.br
}

How to cite: SOUZA, A.A.M., et al. Effects of Stryphnodendron adstringens extracts on murine 4T1 tumor line. Bioscience Journal. 2021, 37, e37055. https://doi.org/10.14393/BJ-v37n0a2021-50347

\begin{abstract}
Breast cancer appears as the main gynecological cancer and presents high morbidity and mortality. Because most diagnoses are made belatedly, it is necessary to seek therapeutic options that aim for advanced stages of the disease. This study aims to evaluate the antitumoral action of Stryphnodendron adstringens fruit extracts on 4T1 murine mammary carcinoma cell culture. The inhibitory potential of $S$. adstringens fruit extract on the metalloproteinases (MMPs) 2 and 9 was evaluated through zymography. From these results, MTT assays were performed to evaluate the extracts' effects on the murine mammary carcinoma 4T1 line cell viability. From the crude extract, the following extracts were obtained: hydroalcoholic (SAFCEA), hexane (SAFCEB), chloroform (SAFCEC), and ethyl acetate (SAFCED). Lastly, the migration of the cells treated with extracts SAFCEA and SAFCED was verified. The hydroalcoholic extract (SAFCEA) was the most efficient in inhibiting gelatinases. During the phytochemical study, it was noted that alkaloids were present in all partitions. The $50 \%$ growth inhibition (IC 50 ) concentrations found were: $40.1 \mu \mathrm{g} / \mathrm{mL}$ (SAFCEA) and 70.14 $\mu \mathrm{g} / \mathrm{mL}$ (SAFCED). After the cellular cytotoxicity assay, cell morphology was altered by treatment with the selected partitions (SAFCEA and SAFCED), obtaining morphology consistent with apoptosis. The results demonstrate that $S$. adstringens extracts exhibit the inhibitory activity of MMP-2 and MMP-9 as well as cytotoxicity toward 4T1 tumor cells. These findings indicate that follow-up studies of the partitions from $S$. adstringens may lead to the development of novel chemotherapeutics for oncological treatments.
\end{abstract}

Keywords: Carcinoma. Cell Culture. Cerrado Plants. Cytotoxicity. Stryphnodendron adstringens.

\section{Introduction}

Breast cancer is the most common malignancy in women, presenting elevated morbidity and mortality rates due to its potential to spread into distant organs such as bone, lungs, liver, and the brain. Thus, metastasis is the main cause of death for breast cancer patients, pressing the search for more effective therapeutic options in advanced stages of the disease (Alipanah et al. 2018). To reach an advanced stage, the malignant cells must go through multiple transformation steps and acquire necessary capacities for tumor progression, namely: sustaining proliferative signalization, evading growth suppressors, resisting cellular death, enabling replicative immortality, inducing angiogenesis, and activating invasion and metastasis (Hanahan and Weinberg 2011). A complex process called Epithelial-Mesenchymal Transition (EMT) regulates the last step, which involves changes in the cellular morphology, loss, and remodeling of 
adhesion molecules with other cells and with the extracellular matrix (ECM) and gaining the capacity to invade and migrate (Sleeman et al. 2012). In this setting, an overexpressed class of enzymes, matrix metalloproteinases (MMPs), stands out. The MMPs belong to a family of zinc-dependent endopeptidases responsible for remodeling and renovating the ECM (Lv et al. 2018). However, in malignant cells, the overexpression of MMPs is associated with the migration potential by exerting effects on the tumor microenvironment and propitiating angiogenesis, tumor growth, and metastasis. This process occurs at high rates since the same tumor cells, healthy fibroblasts and tumor-associated fibroblasts synthesize matrix metalloproteinases. Thus, it may be possible to inhibit metastasis by blocking the expression and activity of the MMPs (Cathcart et al. 2015).

Despite the therapeutic options currently available for treating stage IV metastatic breast cancer, the main objective in this setting is to offer palliative care. Some modalities are hormonal therapy, systemic chemotherapy, surgery, and radiotherapy (Alipanah et al. 2018; lqbal et al. 2018). A source of research for novel therapies is the Brazilian Cerrado, a highly biodiverse biome, home to plants with documented potential for inhibiting carcinogenesis (Carvalho et al. 2019; Neto et al. 2020). Among these herbs, Stryphnodendron adstringens, popularly known in Brazil as Barbatimão, of the Fabaceae family, is popularly used as an antiseptic and in the treatment of leucorrhea, gonorrhea, gastritis, and diarrhea (Mesquita et al. 2009; Souza-Moreira et al. 2018). The plant's bark possesses anti-proliferation and anti-inflammatory properties, as well as recognized scaring properties due to the abundance of tannins, molecules capable of reducing reactive oxygen species (Gali-Muhtasib et al. 2015; Souza-Moreira et al. 2018).

The currently available treatments to patients with advanced-stage breast cancer were not efficient in reducing the mortality rates, thus the objective in studying novel therapeutics as a mean to prolong survival (Heppner et al. 2000; Luo et al. 2014; Cecilio et al. 2015; Hughes et al. 2018; Alipanah et al. 2018; Iqbal et al. 2018). Based on that, this study evaluated the activity of $S$. adstringens extracts on murine breast cancer 4T1 tumor line. The experimental model derives from a highly aggressive murine adenocarcinoma, similar to the human stage IV breast cancer, with the potential to metastasize to bones, lungs, liver, and brain.

\section{Material and Methods}

\section{Collection of plant material}

The plant material was collected from the Cerrado biome $\left(20^{\circ} 8^{\prime} 20^{\prime \prime}, 44^{\circ} 53^{\prime} 2^{\prime \prime}\right)$. Then, a plant exsiccata was deposited in the Herbarium of the Department of Botany of the Universidade Federal de Minas Gerais, under the identification: BHCB 169871.

\section{Preparation of extracts and partitions}

The fresh fruits were washed with distilled water, dried in an incubator at $45{ }^{\circ} \mathrm{C}$ for five days and then, triturated. These samples ( $200 \mathrm{~g}$ ) were exhaustively macerated in a $70 \%$ hydroalcoholic solution to extract the fruit's components. The macerate was later filtered, frozen $\left(-80^{\circ} \mathrm{C}\right)$ and lyophilized, obtaining the S. adstringens fruit crude extract (SAFCE).

The S. adstringens fruit crude extract (SAFCE) was weighed, then $10.0 \mathrm{~g}$ were solubilized in hydroalcohol (70\%). The resulting solution was placed in a separation funnel, in which $150 \mathrm{~mL}$ of hexane solvent were added and stirred with a magnetic agitator for 10 minutes. This process was repeated twice resulting in $450 \mathrm{~mL}$ of the hexanic partition. The remaining SAFCE solution was submitted to the same procedures as the other solvents: chloroform, ethyl acetate. The resulting extracts were labeled: A (hydroalcoholic - equivalent to rest of the solution), B (hexanic), C (chloroform), and D (ethyl acetate) then submitted to rotary evaporation and subsequently lyophilization.

\section{Zymogram}

The proteolytic activity of MMP-2 and MMP-9 was measured by gelatin zymography following (Ribeiro et al. 2010; Santos et al. 2015). In all the tests, $5 \mu \mathrm{L}$ of each extract sample at a concentration of 0.01 $\mathrm{g} / \mathrm{mL}$ in dimethyl sulfoxide (DMSO) was added to each well of the gel. Then $1.5 \mu \mathrm{L}$ of MMP-2 and MMP-9 
(Sigma-AldrichChemie, M9445 and M8945, respectively) were added at a concentration of $1.8 \mu \mathrm{g} / \mathrm{mL}$ with buffer of $2.5 \mathrm{~g} \%$ SDS, $1 \mathrm{~g} \%$ sucrose, $4 \mu \mathrm{g} / \mathrm{mL}$ red phenol. Wells loaded only with MMPs, and buffer were established as standard (positive control). Using the electrophoresis technique (Bio-Rad - PowerPac ${ }^{\mathrm{TM}} \mathrm{HC}$ High-Current), the gels were maintained at a voltage of $70 \mathrm{~V}$ for $3 \mathrm{~h}$ at $40 \mathrm{C}$ in $0.025 \mathrm{M}$ TRIS, $0.192 \mathrm{M}$ glycine and $0.1 \%$ SDS buffer, $\mathrm{pH}$ 8.5. After this process, the gels were washed in $2.5 \%(\mathrm{v} / \mathrm{v})$ Triton- $\mathrm{X}$ for $1 \mathrm{~h}$, to remove the SDS. To stimulate the proteolytic activity of MMPs, the gels were immersed in the activation buffer $(0.05$ $\mathrm{M}$ TRIS- $\mathrm{HCl}$ and $6 \mathrm{mM} \mathrm{CaCl} 2, \mathrm{pH} 8.0$ ) for $16 \mathrm{~h}$ and $37 \stackrel{\circ}{\circ} \mathrm{C}$. The gels were washed in distilled $\mathrm{H}_{2} \mathrm{O}$ and stained ( $0.25 \%$ Coomassie blue R-250, 45\% methanol, and $10 \%$ acetic acid) for $1 \mathrm{~h}$ while shaking. Then, they were bleached (30\% ethanol and $10 \%$ acetic acid) for $1 \mathrm{~h}$. The digital images were subjected to analysis of the white area and were classified using Image J 1.8.0. The results are expressed as the percentage of inhibition of gelatinolytic activity caused by the extracts. Statistical analyzes of all the zymograms were performed in triplicate, and the statistical analysis was based on unpaired t test of One-way ANOVA $(p<0.0001)$.

\section{Column chromatography fractionation}

To obtain the fractions of plant components from the hydroalcoholic partition (A) of the SAFCE (SAFCEA) which the MMPs, $0.4 \mathrm{~g}$ of the sample were solubilized in methanol and $4.08 \mathrm{~g}$ of silica gel 60 , and dried in an incubator at $40^{\circ} \mathrm{C}$. The silica $(0.05-0.20 \mathrm{~mm} \mathrm{170-270} \mathrm{Mesh)} \mathrm{was} \mathrm{dissolved} \mathrm{in} \mathrm{hexane} \mathrm{and} \mathrm{then}$ poured into a column. Later, the sample containing silica was also added to the column with hexane. The solvents used for elution were hexane, chloroform, ethyl acetate, methanol, and distilled water. To gradually increase the polarity of the system, mixtures of the solvents were used in different proportions (Table 1).

Table 1. Solvents and their respective proportions used in the fractionation by column chromatography.

\begin{tabular}{cc}
\hline Solvent & Proportion \\
\hline Hexane & 1 \\
Chloroform & $1: 5$ \\
Chloroform/Ethyl acetate & 1 \\
Ethyl acetate & $1: 5$ \\
Ethyl acetate/Methanol & 1 \\
Ethyl acetate/Methanol & $5: 1$ \\
Methanol & $1: 1$ \\
Methanol/Distilled water & 1 \\
Methanol/Distilled water & $1: 1$ \\
\hline
\end{tabular}

\section{Chromatographic profile}

Glass plates were prepared with silica for thin-layer chromatography (silica gel, size: 10-40 $\mu \mathrm{m}$, Binder: $\mathrm{CaSO}_{4}$, Type GF). They dried at room temperature and were subsequently activated in a drying oven at $100{ }^{\circ} \mathrm{C}$. Samples of the partition products were applied to the plates to evaluate their chromatographic profile. For this, the plates were eluted in ethyl acetate: acetic acid: water, respectively. For development with vanillin, the plate was sprinkled with a $1 \%$ vanillin solution in ethanol and then sprinkled with a $10 \%$ sulfuric acid solution in ethanol in an equivalent amount as the former. Subsequently, the plate was heated in a heating plate.

\section{Phytochemical testing - identifying secondary metabolites}

Each partition underwent phytochemical tests to identify secondary compounds based on visual observations of color modification or precipitate formation from specific chemical reactions was performed according to Matos (2009). Each partition (10 mg) was dissolved in $10 \mathrm{ml}$ of the hydro alcohol solution (70\%) and the tests determine the presence or absence of a compound phytochemical (tannins, coumarins, steroids, triterpenes, saponins, flavonoids, alkaloids) in the extract. 


\section{Cell culture conditions}

Murine mammary adenocarcinoma cells (4T1) were maintained in RPMI-1640 culture medium, supplemented with fetal bovine serum (FBS) $10 \%$ and streptomycin/penicillin $(\mathrm{s} / \mathrm{p}) 1 \%(\mathrm{v} / \mathrm{v})$. All cells were maintained in an oven at $37{ }^{\circ} \mathrm{C}$ in a humidified atmosphere enriched with $5 \%(\mathrm{v} / \mathrm{v}) \mathrm{CO} 22$, at $37^{\circ} \mathrm{C}$. Confluent monolayers were dissociated with $0.25 \%$ trypsin-EDTA (Life Technologies). Cells of the logarithmic growth phase were used in all experiments. All experiments were performed in triplicate experimental and biological.

\section{Viability assays of murine cell lines}

The effects of the extracts on the $4 \mathrm{~T} 1$ cell line viability cells were evaluated by MTT [3- (4,5dimethylthiazol-2yl) -2,5-diphenyltetrazolium] assay. The cells were cultured in RPMI medium supplemented with $10 \%$ fetal bovine serum (FBS) and then, were plated in 96-well plates ( $2 \times 10$ cells/well) and incubated for 24 hours in $5 \% \mathrm{CO}_{2}$, at $37^{\circ} \mathrm{C}$. After this period, they were treated with the fractions diluted in DMSO (1\%) in different concentrations $(25 \mu \mathrm{g} / \mathrm{mL}, 50 \mu \mathrm{g} / \mathrm{mL}, 75 \mu \mathrm{g} / \mathrm{mL}$, and $100 \mu \mathrm{g} / \mathrm{mL}$ ). The cisplatin was used as a positive control $(30 \mu \mathrm{g} / \mathrm{mL}$ ) (Santos et al. 2019). The vehicle control (DMSO, 1\%) received the dilution vehicle from the extracts diluted in RPMI culture medium. After 24 hours, MTT $(0,05 \mathrm{mg} / \mathrm{mL})$ was added and allowed to incubate for $3 \mathrm{hrs}$. The plate was read on the spectrophotometer with a $570 \mathrm{~nm}$ filter at room temperature. The control was considered $100 \%$ cell viability and IC50 was calculated using GraphPad prism 7 , with regression no linear.

\section{Morphology}

The $4 \mathrm{~T} 1$ cells were treated separately with the partitions $A$ and $\mathrm{D}(25 \mu \mathrm{g} / \mathrm{mL}$ and $75 \mu \mathrm{g} / \mathrm{mL})$ and with cisplatin $(20 \mu \mathrm{g} / \mathrm{mL})$ for 24 hours. The wells were photographed at $400 \times$ magnification with ZEN 2.3 software (Carl Zeiss Microscopy GmbH) on an inverted Zeiss Axio Vert A1 MAT microscope, and then, analyzed for their morphology.

\section{Wound healing assay}

4T1 cells were cultured in a 24-well plate containing RPMI-1640 medium and $10 \%$ FBS. After confluence, two wounds were performed in each well (two well for assays). Wounds were washed with PBS to remove supernatant cells and then treatments (IC50) with $0.1 \%$ bovine serum albumin as vehicle control were then added. Images of the wounds were obtained at times of $0,24,48$, and $72 \mathrm{~h}$ (Wang et al. 2018). At indicated time points, the cells were photographed with AXIO VERT A1 FL (CARL ZEISS ${ }^{\circledR}$ ) (400X). The images were analyzed in the ZEN 2.3 program (Carl Zeiss Microscopy $\mathrm{GmbH}$ ) and the statistical analysis was done in GraphPad Prism 7 (GraphPad Software, Inc.) using the one-way ANOVA test.

\section{Results}

The S. adstringens fruit crude extract (SAFCE) was chosen to be the object of study because it presented the greatest inhibitory potential of MMP-2 (88,3\%) and MMP-9 $(53,4 \%)$ between the parts of the plant, in zymography evaluation (Figure 1). Between the SAFCE partitions showed that the hydroalcoholic (SAFCEA) was the most effective in inhibiting the activity of MMP-2 (97.7\%) and MMP- 9 (86.9 \%) (Figure 2). Then, with the fractionation of SAFCEA, the eight fractions resulting were grouped according to their phytochemical profile and then submitted to the zymogram. All tested fractions were able to inhibit the gelatinolytic activity of MMP-9, especially fraction $2(20,0 \%)$. The other fractions $20 \%$ inhibition was not achieved. Fraction 8 also stood out in relation to the inhibition of MMP-2 (42,6\%) (Figure 3). 

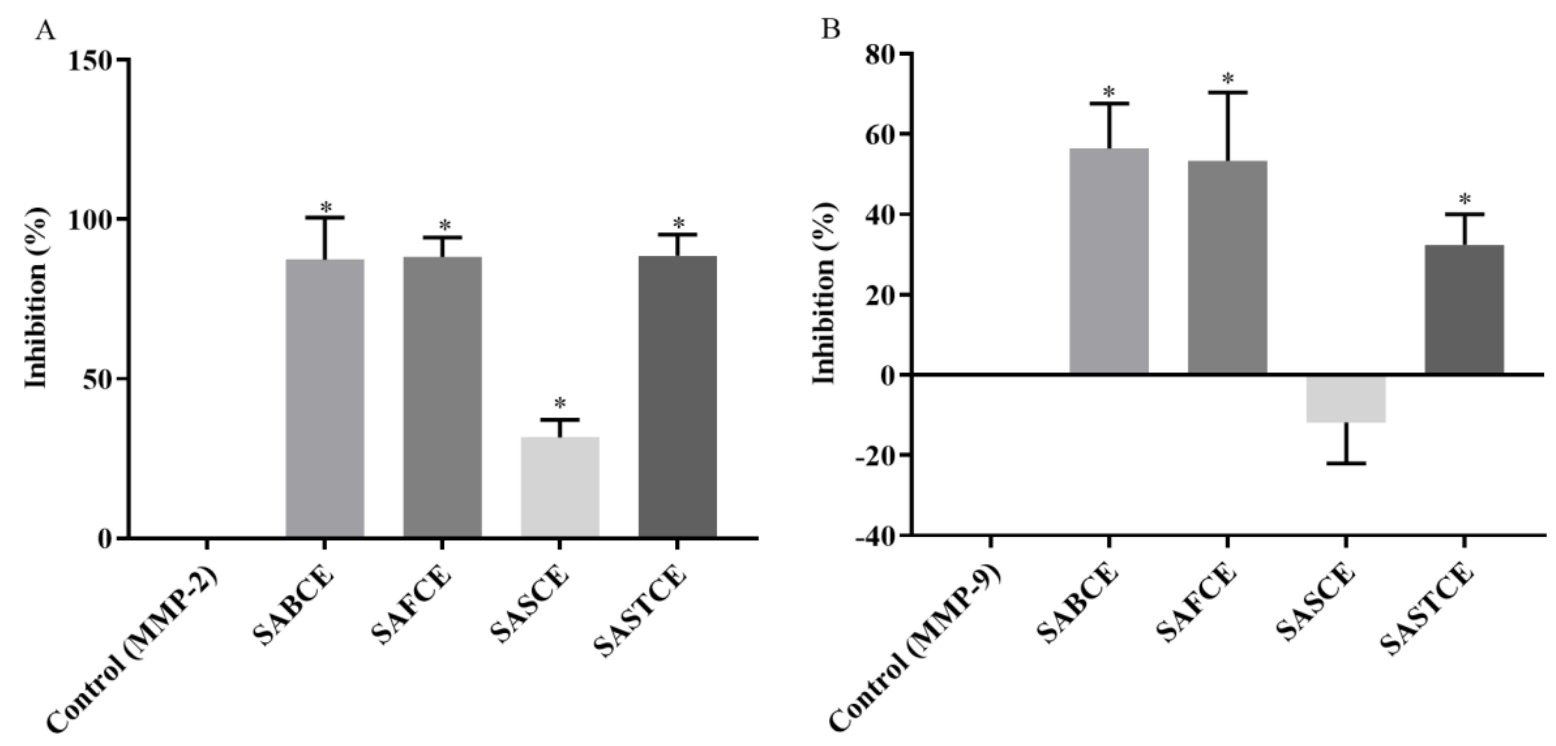

Figure 1. MMP-2 and MMP-9 gelatinolytic activity inhibition from the crude extracts (SABCE = Bark, SAFCE $=$ Fruit, SASCE $=$ Seed, SASTCE $=$ Stem). A - MMP-2; B - MMP-9. The statistical analysis was based on OneWay ANOVA. $\mathrm{p}$ value $=*<0.0001$. Bars $=$ SD.
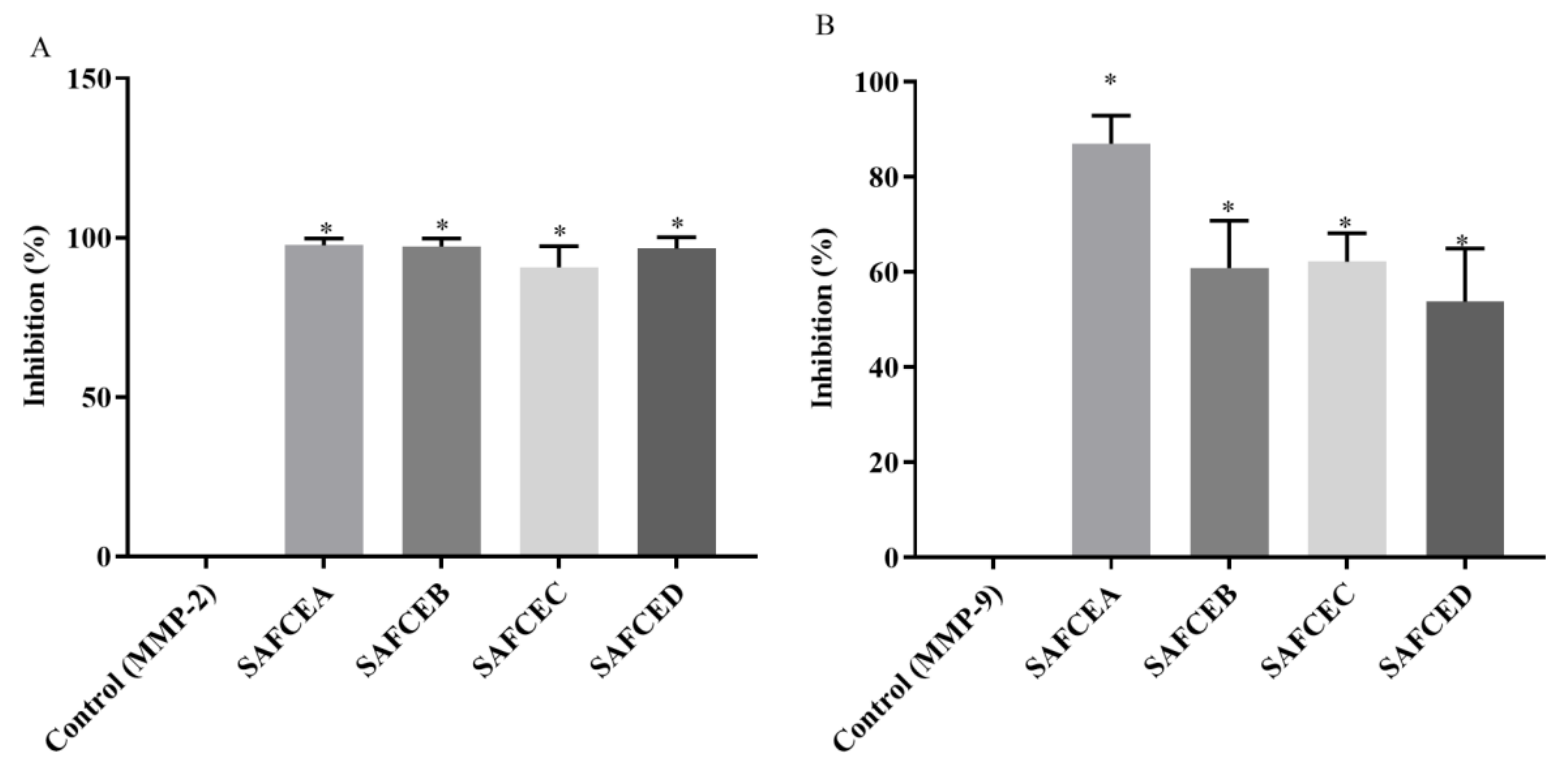

Figure 2. MMP-2 and MMP-9 gelatinolytic activity inhibition from the crude extract derivatives (SAFCEA Hydroalcoholic; SAFCEB - Hexanic; SAFCEC - Chloroform; SAFCED - Ethyl Acetate). A - MMP-2; B - MMP-9. The statistical analysis was based on One-Way ANOVA. $p$ value $=*<0.0001$. Bars $=$ SD. 

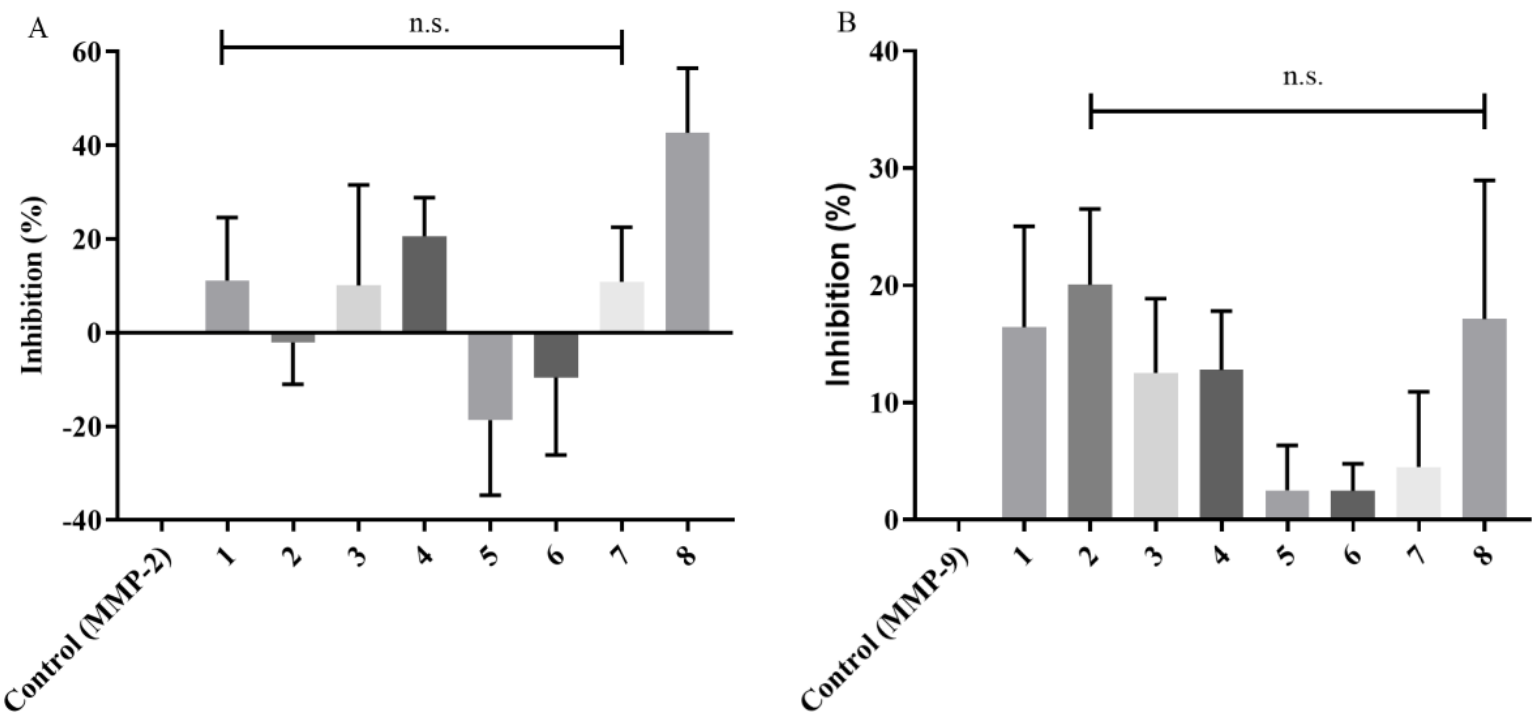

Figure 3. MMP-2 and MMP-9 gelatinolytic activity inhibition from fruit fractions (SAFCEA). A - MMP-2; B MMP-9. The statistical analysis was based on One-Way ANOVA. Bars = SD. n.s.= no significant.

Phytochemical analysis showed only alkaloids in all the partitions. Steroids, flavonoids, saponins, and tannins were founded only in the crude extract and in the hydroalcoholic partition. Coumarins were founded in the crude extract and in the hydroalcoholic and ethyl acetate partitions (Table 2).

Table 2. SAFCE and partitions phytochemical study.

\begin{tabular}{cccccc}
\hline Extract & SAFCE & SAFCEA & SAFCEB & SAFCEC & SAFCED \\
\hline Steroids & + & + & - & - & - \\
Flavonoids & + & + & - & - & - \\
Saponins & + & + & - & - & - \\
Tannins & + & + & - & - & - \\
Coumarins & + & + & + & + & + \\
Alkaloids & + & + & + \\
\hline
\end{tabular}

SAFCEA: Hydroalcoholic; SAFCEB: Hexanic; SAFCEC: Chloroformic; SAFCED: Ethyl acetate; +: presence; -: absence.

\section{Hydroalcoholic and ethyl acetate extracts of $S$. adstringens are cytotoxic to 4T1}

The effects of SAFCE and its derivatives (SAFCEA, SAFCEB, SAFCEC, SAFCED) on cell viability of the 4T1 line were analyzed by the viability assay (Figure 4). The values of the $I C_{50}$ are shown in Table 3. Partitions with the lowest IC 50 values were selected for the continuity of the experiments, with SAFCEA and SAFCED $(40.1 \mu \mathrm{g} / \mathrm{mL}$ ) and $70.14 \mu \mathrm{g} / \mathrm{mL}$, respectively) (table 3 and figure 4$)$.

Table 3. $I C_{50}$ values of $S$. adstringens fruit extracts.

\begin{tabular}{cccccc}
\hline Extract & SAFCE & SAFCEA & SAFCEB & SAFCEC & SAFCED \\
\hline $\mathrm{IC} 50(\mu \mathrm{g} / \mathrm{mL})$ & - & 40,1 & - & - & 70,14 \\
\hline
\end{tabular}

"-": values higher than the curve's previously established upper limit. 


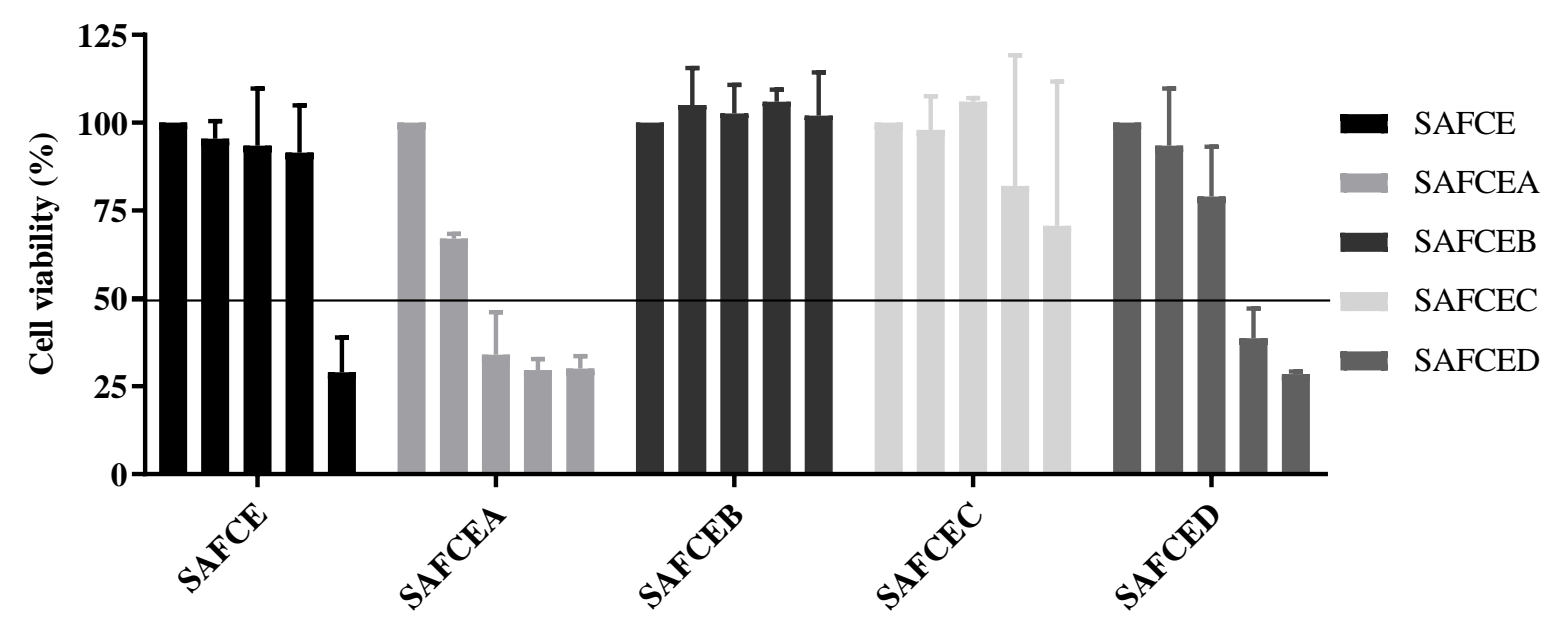

Figure 4. Cell viability (\%) $\times$ Concentration $(\mu \mathrm{g} / \mathrm{mL})$. From left to right, each test received negative control fractions (DMSO) and SAFCEA, SAFCEB, SAFCEC, SAFCED: $25 \mu \mathrm{g} / \mathrm{mL}, 50 \mu \mathrm{g} / \mathrm{mL}, 75 \mu \mathrm{g} / \mathrm{mL}$, and $100 \mu \mathrm{g} / \mathrm{mL}$. The statistical analysis was based on One-Way ANOVA. Bars = SD.

\section{S. adstringens extracts cause morphologic alterations}

Treated and untreated cells were photographed. Cells from the untreated 4T1 line presented an elongated shape, exhibiting typical projections with a concentration of $75 \mu \mathrm{g} / \mathrm{mL}$ in both treatments. 4T1 cells treated with the extracts demonstrated a rounded shape and decreased projections, as well as condensed chromatin, similar to the treatment with cisplatin. There was also a reduction in the number of viable cells in these wells (Figure 5).
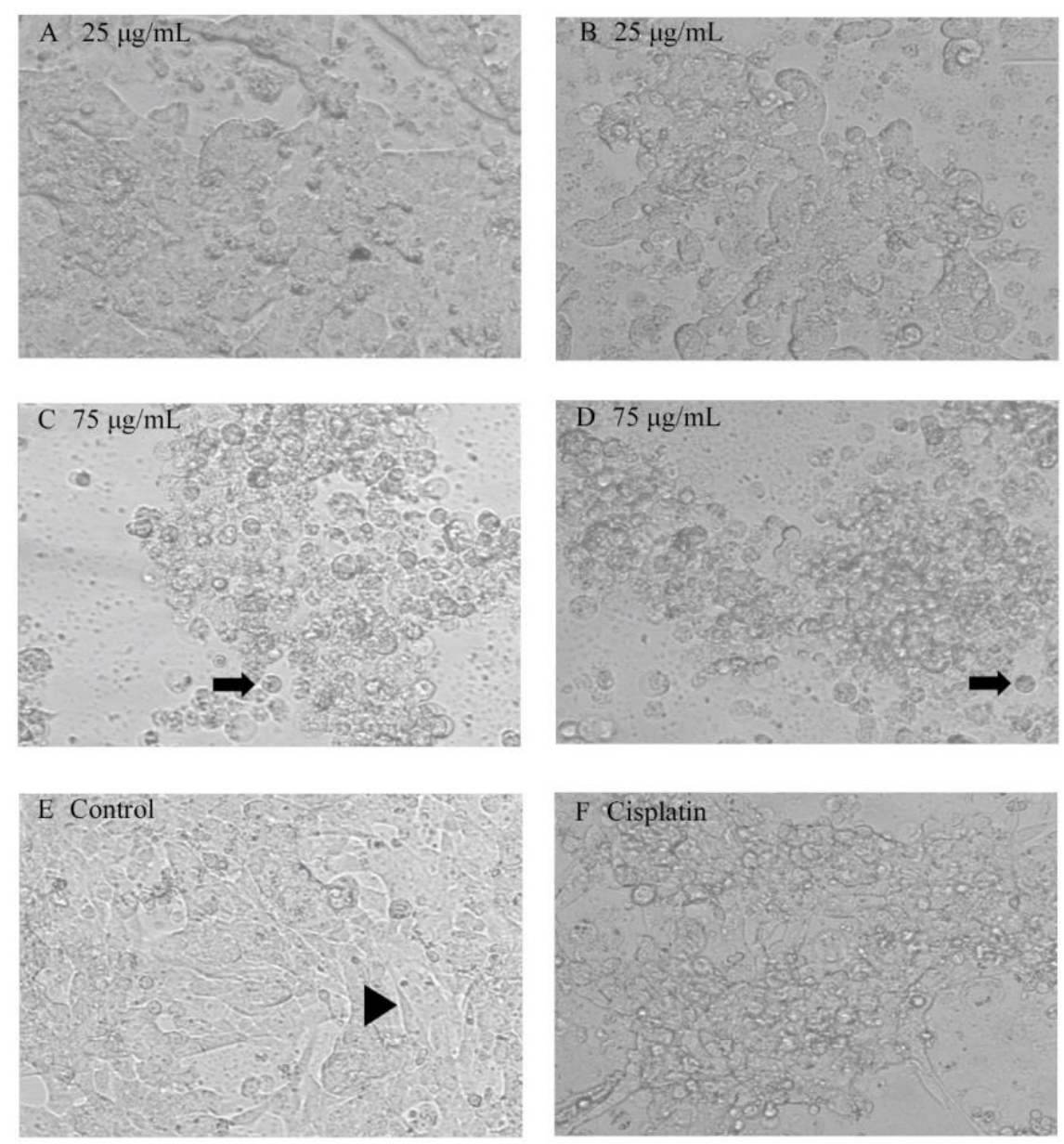

Figure 5. 24-hour cell morphology. A - SAFCEA $(25 \mu \mathrm{g} / \mathrm{mL}) ;$ B - SAFCED $(25 \mu \mathrm{g} / \mathrm{mL}) ; C$ - SAFCEA $(75 \mu \mathrm{g} / \mathrm{mL})$; D - SAFCED ( $75 \mu \mathrm{g} / \mathrm{mL}$ ); E - Control (culture medium); F - cisplatin-treated 4T1 cells (positive control).

Arrows: smaller and rounded cells. Arrowhead: 4T1 typical morphology. 


\section{Wound closure}

The cell migration test results with SAFCEA were statistically significant and demonstrated a decrease in cellular migration in 48 hours $(p=0.0002)$ and in 72 hours $(p=0.0001)$. In 24 hours, the wound was $7 \%$ open, which increased to $20 \%$ in 48 and 72 hours (Figure 6). Treatment with SAFCED was not a statistically significant difference when compared to control (Figure 7).

Final images of the cell migration assay (Figure 8) demonstrate the confluence of the untreated cells (Control - DMSO), which after 24 hours, the wound was reduced to $3.3 \%$ of its original size. In 72 hours, the wound was reduced to $0.6 \%$. These effects were less notable for SAFCEA and SAFCED, with which the wound maintained open spaces.

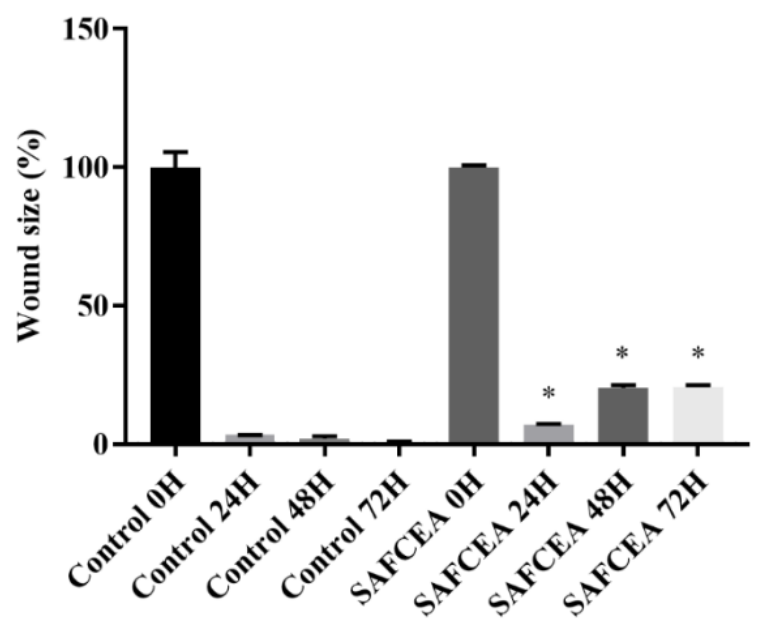

Time

Figure 6. Treatment with partition SAFCEA - cell migration assay. Wound size (\%) $x$ Treatment with Control (DMSO 1\%) and partition SAFCEA in 0, 24, 48 and 72 hours. The statistical analysis was based on One-Way ANOVA. $p$-value $=*=0.0002$. Bars $=$ SD.

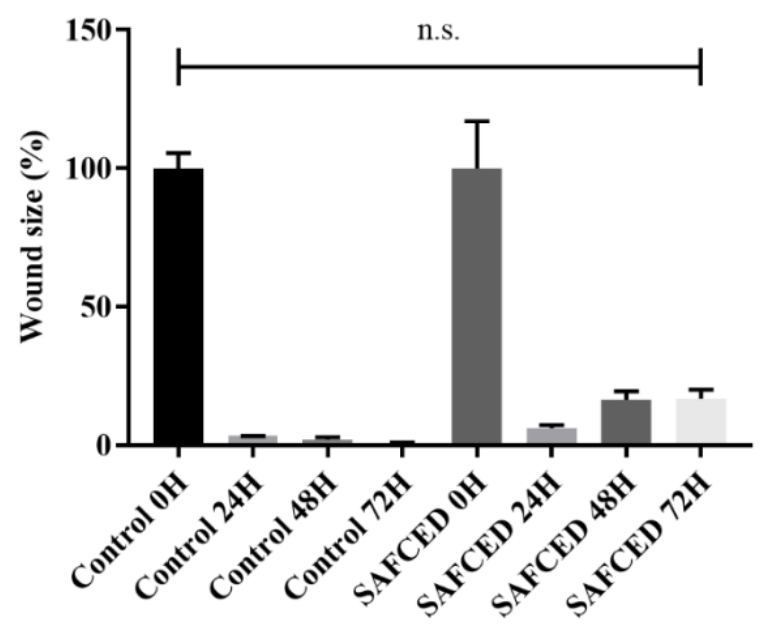

Time

Figure 7. Treatment with partition SAFCED - Cell migration test. Wound size (\%) $x$ Treatment with control (DMSO 1\%) and partition SAFCED at 0, 24, 48 and 72 hours. The statistical analysis was based on One-Way ANOVA. Bars = SD. n.s. = no significant. 


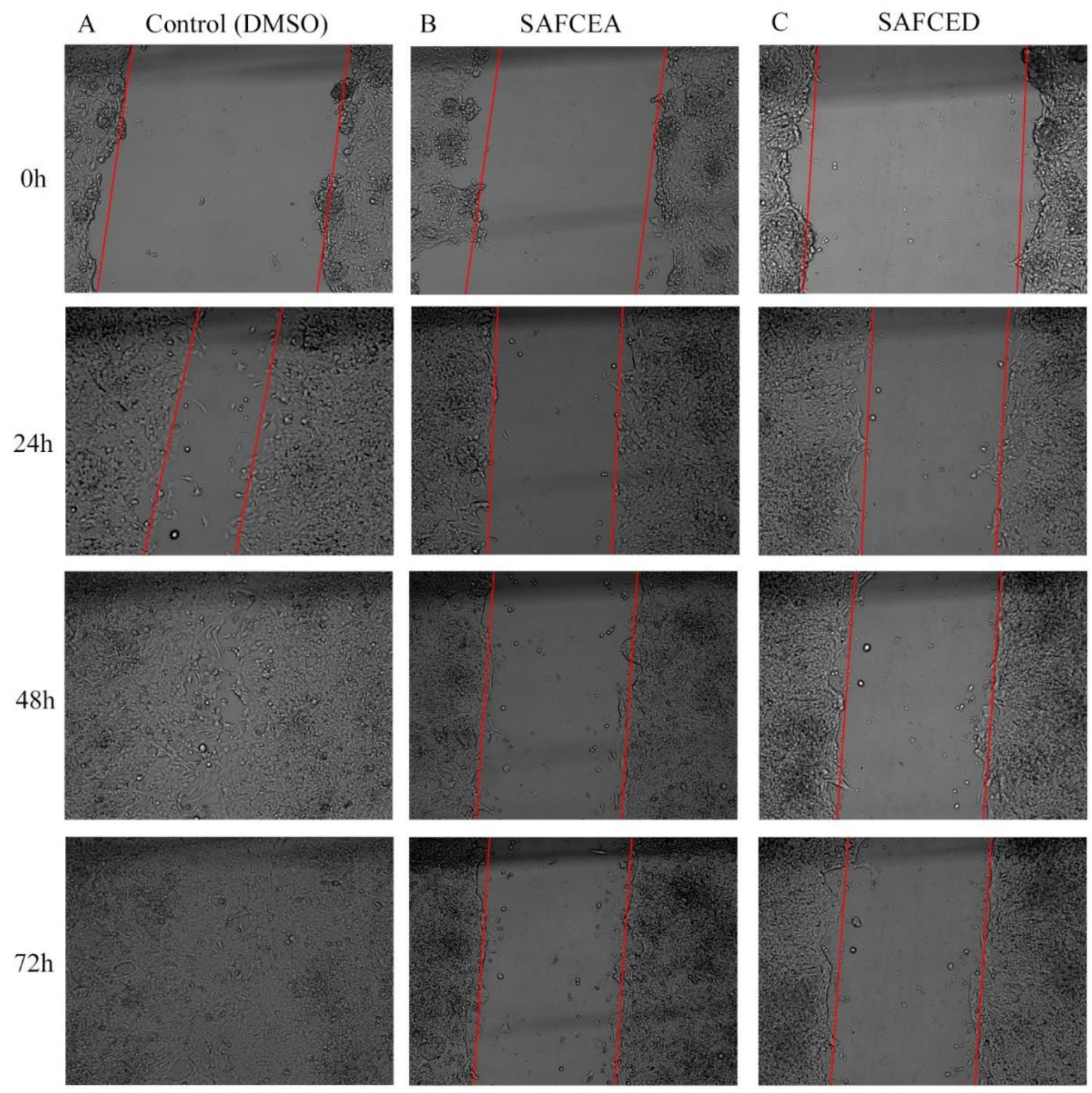

Figure 8. Cell migration assay showing the evolution of cells in control medium, partition $A$ and partition $D$ at $0,24,48$, and 72 hours. A - DMSO; B - SAFCEA; C - SAFCED.

\section{Discussion}

This study aimed to evaluate the action of $S$. Adstringens fruit extracts on the MMPs activity as well as on murine breast cancer 4T1 tumor, in vitro. It was demonstrated that the $S$. Adstringens fruit crude extract (SAFCE) promoted the inhibition of the gelatinolytic activity of MMPs 2 and 9. Through the phytochemical study, steroids, coumarins, alkaloids, saponins, tannins, and flavonoids were found in both the SAFCE and in its derivative SAFCEA. It was also observed that the SAFCEA and SAFCED derivatives caused significant reducing cell viability on the 4T1 cells and were responsible for the lowest IC50 values found. The cytotoxic effect of the cited extracts was also confirmed by the morphology assay, in which the treated cells demonstrated changes that suggest cell death by apoptosis. However, more accurate tests, such as apoptotic or nuclear markers, that could assess more precisely the cell death pathway, will be necessary to confirm this hypothesis. Finally, it was found that the SAFCEA significantly reduced the migratory activity of 4T1 cells.

Cell invasiveness is dependent on functional secreted enzymes, especially MMP-2 and MMP-9, capable of catalyzing the proteolytic cleavage of the extracellular matrix and basal lamina components (Lin et al. 2018). In this study, we found that SAFCEA and SAFCED derivatives inhibit in vitro gelatinolytic activity of both MMP-2 and 9, which a process that could also impact in the metastatic potential of murine breast cancer 4T1 tumor. Thus, the activity demonstrated by the SAFCEA and SAFCED derivatives provides the need for compounds that impact on the replicative phenotype of invasion and metastasis that becomes so imperative. 
On the cell viability assay, SAFCE as well as both SAFCEA and SAFCED were shown to be significantly cytotoxic toward 4T1 cells. This behavior may be related to a class of secondary metabolites, the coumarins, found in all extracts and which harbor known antioxidant, antiangiogenic, antimutagenic, anti-inflammatory, and cell differentiation inhibitory potentials, in addition to being cytotoxic to some human tumor lines (Chan et al. 2017). Another class of secondary metabolites, the alkaloids, was present in all these partitions. This finding suggests that the cytotoxic activity may also be associated with the already acknowledged antitumor effect of this substance group (Barbosa-Filho et al. 2006), possibly in synergism with the coumarins' activity. In addition, confirmed biological activities, including anti-inflammatory, antioxidant, and antimicrobial activities, were related to the presence of compounds of the tannin class (Souza-Moreira et al. 2018).

The secondary compounds found in SAFCE and SAFCEA are important in preventing tumor formation by modulating carcinogenic metabolism, regulating the expression of oncogenes and tumor suppressor genes, antioxidant and free radical scavenging activity, and modulating cell proliferation and differentiation, among other mechanisms (Lu et al. 2012; Huang et al. 2009). In addition, the more potent cytotoxic effects of SAFCE and SAFCEA when compared to other extracts also may be associated with the presence of saponins and flavonoids. Saponins are metabolites that, in addition to altering the permeability of the cell membrane, inhibit the cell cycle by increasing p16 and p21. They also induce apoptosis by interfering in the expression of p53, Fas, FasL, and caspases 1,3,7, and 8 (Koczurkiewicz 2014). On the other hand, flavonoids have a prooxidant action in the presence of transition metals, which is responsible for cytotoxicity mainly because it causes damage to the DNA. This property is highlighted because tumor cells have higher intracellular Cu (II) concentrations, being more affected than non-tumor cells (Elias 2015). The sum of these factors suggests a synergism between these metabolites, contributing to the cytotoxic effect of this partition for the 4T1 cell line.

In contrast, it was verified in the cell culture that the SAFCEA and SAFCED presented increased cell viability when compared to the negative control, reaching a maximum of $114.6 \%$. This may be related to the well-recognized wound healing effect of $S$. adstringens, since several studies have found an accelerated epithelization process during treatment with the extracts of this plant (Coelho 2009; Costa 2013; Luiz 2015).

Concerning the cell morphology observations, the obtained results corroborate the potency of the toxic effect of both SAFCEA and SAFCED on the 4T1 cell line, which resulted in changes in the cellular morphology, straying from the standard pattern. The appearance of the treated cells was like that identified on cisplatin-treated cells, which include chromatin condensation, alteration on the symmetry of cell membrane, and DNA fragmentation, which are morphological changes typically attributed to apoptosis (Sorenson et al. 1990; Alamzadeh et al. 2019). Finally, we found in this study that SAFCEA treated cells showed reduced mobility, suggesting inhibition of cell migration, as the wound remained open, and the assay follow-up revealed was an increase in its extent.

It is important to note that cell mobility is dependent on the proteins of the cytoskeleton and also on their involvement with those in the extracellular environment (Ong et al. 2020). Furthermore, the inhibition of the gelatinolytic activity of MMPs as demonstrated in this study may be related to the reducing migratory potential of tumor cells cultivated in vitro (Lin et al. 2014; Nho et al. 2015) since the overexpression of these enzymes correlates with this capacity (Cathcart et al. 2015). This process occurs through the degradation of adhesion molecules, which compose the extracellular matrix, as well as the release of proangiogenic and growth factors in this microenvironment, favoring the mobility of neoplastic cells (Rundhaug 2005). Thus, it is possible that the characteristic of reduction of the cellular mobility observed in the wound clousure assay, in association with the inhibition of the gelatinolytic activity of MMPs, may contribute to the reduction of invasion and consequently, the metastatic cascade, are what make cancers, including breast cancer, so aggressive (Kozłowski et al. 2015).

\section{Conclusions}

The fruit extracts of $S$. adstringens, known by the popular name Barbatimão, showed cytotoxic activity to cells of the 4T1 cell line as well as inhibitory activity for MMP-2 and MMP-9, revealing an antimigratory potential based on characteristics of the experimental model used. Thus, it is expected that the data obtained will stimulate future more in-depth investigations on the fruit extracts of $S$. adstringens that may provide development on alternative oncological treatments. 
Authors' Contributions: SOUZA, A.A.M.: conception and design, acquisition of data, analysis and interpretation of data, drafting the article; GERVÁSIO, E.R.: analysis and interpretation of data, drafting the article; PAULA, T.P.: acquisition of data, analysis and interpretation of data; NETO, L.R.S.: acquisition of data, analysis and interpretation of data; FERNANDES, F.P.C.: acquisition of data, analysis and interpretation of data; LEITE, G.F.: acquisition of data, analysis and interpretation of data; BARRETO, F.P.: acquisition of data, analysis and interpretation of data; RIBEIRO, R.I.M.A.: analysis and interpretation of data, drafting the article. All authors have read and approved the final version of the manuscript.

Conflicts of Interest: The authors declare no conflicts of interest.

Ethics Approval: Not applicable.

Acknowledgments: The authors would like to thank the funding for the realization of this study provided by the Brazilian agencies FAPEMIG (Fundação de Amparo à Pesquisa do Estado de Minas Gerais - Brasil), Finance Code PPM-00229-16 and APQ-00068-18.

\section{References}

ALAMZADEH, Z., et al. Ultrastructural and optical characteristics of cancer cells treated by a nanotechnology-based chemo-photothermal therapy method. Journal of Photochemistry \& Photobiology, B, Biology. 2019, 192(1), 19-25. https://doi.org/10.1016/i.jphotobiol.2019.01.005

ALIPANAH, H., BIGDELI, M.R. and ESMAEILI, M.A. Inhibitory Effect of Viola odorata Extract on Tumor Growth and Metastasis in 4T1 Breast Cancer Model. Iranian journal of pharmaceutical research: IJPR. 2018, 17(1), 276-291. https://dx.doi.org/10.22037/ijpr.2018.2149

BARBOSA-FILHO, J.M., et al. Anti-inflammatory activity of alkaloids: a twenty-century review. Revista Brasileira de Farmacognosia. 2006, 16(1), 109-134. https://doi.org/10.1590/S0102-695X2006000100020

CARVALHO, J.T.G., et al. Medicinal Plants from Brazilian Cerrado: Antioxidant and Anticancer Potential and Protection against Chemotherapy Toxicity. Oxidative Medicine and Cellular Longevity. 2019, 2019(1), 1-16. https://doi.org/10.1155/2019/3685264

CATHCART, J., PULKOSKI-GROSS, A. and CAO, J., Targeting matrix metalloproteinases in cancer: bringing new life to old ideas. Genes \& diseases. 2015, 2(1), 26-34. https://doi.org/10.1016/j.gendis.2014.12.002

CECILIO, A.P., et al. Breast cancer in Brazil: epidemiology and treatment challenges. Breast Cancer: Targets and Therapy. 2015, 7(1), 43-49. https://doi.org/10.2147/BCTT.S50361

CHAN, L.P., et al. IL-8 promotes inflammatory mediators and stimulates activation of p38 MAPK/ERK-NF-KB pathway and reduction of JNK in HNSCC. Oncotarget. 2017, 8(34), 56375-56388. https://doi.org/10.18632/oncotarget.16914

COELHO, J.M., et al. O efeito da Sulfadiazina de prata, extrato de Ipê-roxo e extrato de Barbatimão na cicatrização de feridas cutâneas, em ratos. Revista do Colégio Brasileiro de Cirurgia. 2010, 37(1), 45-51. http://dx.doi.org/10.1590/S0100-69912010000100010

COSTA, M.A., et al. Acute and Chronic Toxicity of an Aqueous Fraction of the Stem Bark of Stryphnodendron adstringens (Barbatimão) in Rodents. Evidence-Based Complementary and Alternative Medicine. 2013, 2013(1), 1-9. https://doi.org/10.1155/2013/841580

MESQUITA, M.L., et al. Cytotoxic activity of Brazilian Cerrado plants used in traditional medicine against cancer cell lines. Journal of ethnopharmacology. 2009, 123(3), 439-445. https://doi.org/10.1016/i.jep.2009.03.018

ELIAS, S.T., et al. Radiation induced a supra-additive cytotoxic effect in head and neck carcinoma cell lines when combined with plant extracts from Brazilian Cerrado biome. Clinical Oral Investigations. 2015, 19(3), 637-646. https://doi.org/10.1007/s00784-014-1289-z

GALI-MUHTASIB, H., et al. Cell death mechanisms of plant-derived anticancer drugs: beyond apoptosis. Apoptosis. 2015, 20(12), 1531-1562. https://doi.org/10.1007/s10495-015-1169-2

HANAHAN, D. and WEINBERG, R.A. Hallmarks of Cancer: The Next Generation. Cell. 2011, 144(5), 646-674.

https://doi.org/10.1016/j.cell.2011.02.013

HEPPNER, G.H., MILLER, F.R. and SHEKHAR, P.M. Nontransgenic models of breast cancer. Breast Cancer Research. 2000, 2(5), $331-334$. https://doi.org/10.1186/bcr77

HUANG, W.Y., CAI, Y.Z. and ZHANG, Y. Natural phenolic compounds from medicinal herbs and dietary plants: potential use for cancer prevention. Nutrition and cancer. 2009, 62(1), 1-20. https://doi.org/10.1080/01635580903191585

HUGHES, V.S. and SIEMANN, D.W. Treatment with Src inhibitor Dasatinib results in elevated metastatic potential in the 4T1 murine mammary carcinoma model. Tumor \& microenvironment. 2018, 1(1), 30-36. https://doi.org/10.4103/tme.tme_19_17

IQBAL, J., et al. Potential phytocompounds for developing breast cancer therapeutics: Nature's healing touch. European journal of pharmacology. 2018, 827(15), 125-148. https://doi.org/10.1016/j.ejphar.2018.03.007

KOCZURKIEWICZ, P., et al. Multidirectional effects of triterpene saponins on cancer cells - mini-review of in vitro studies. Acta biochimica Polonica. 2014, 62(3), 383-393. https://doi.org/10.18388/abp.2015_1089

KOZŁOWSKI, J., KOZŁOWSKA A. and KOCKI, J. Breast cancer metastasis - insight into selected molecular mechanisms of the phenomenon. Postepy higieny i medycyny doswiadczalnej (Online). 2015, 69(1), 447-451. https://doi.org/10.5604/17322693.1148710

LIN, C.Y., et al. Inhibition of the invasion and migration of renal carcinoma 786-o-si3 cells in vitro and in vivo by Koelreuteria formosana extract. Molecular Medicine Reports. 2014, 10(6), 3334-3342. https://doi.org/10.3892/mmr.2014.2587 
LIN, H., et al. Iron (II)-polypyridyl complexes inhibit the growth of glioblastoma tumor and enhance TRAIL-induced cell apoptosis. Chemistry an Asian Journal. 2018, 13(18), 2730-2738. https://doi.org/10.1002/asia.201800862

LU, P., WEAVER, V.M. and WERB, Z. The extracellular matrix: A dynamic niche in cancer progression. The Journal of Cell Biology. 2012, 196(4), 395-406. https://doi.org/10.1083/jcb.201102147

LUIZ, R.L.F., et al. Proanthocyanidins polymeric tannin from Stryphnodendron adstringens are active against Candida albicans biofilms. BMC Complementary and Alternative Medicine. 2015, 15(68), 1-11. https://doi.org/10.1186/s12906-015-0597-4

LUO, K.W., et al. In vivo and in vitro anti-tumor and anti-metastasis effects of Coriolus versicolor aqueous extract on mouse mammary 4T1 carcinoma. Phytomedicine. 2014, 21(8-9), 1078-1087. https://doi.org/10.7150/thno.23209

LV, Y., et al. Targeting intracellular MMPs efficiently inhibits tumor metastasis and angiogenesis. Theranostics. 2018, 8(10), $2830-2845$. https://doi.org/10.7150/thno.23209

MATOS, F.J.A. Introdução a fitoquímica experimental. 3th ed. Fortaleza: Edições UFC, 2009.

NHO, K.J., CHUN, J.M., KIM, D.S. and KIM, H.K. Ampelopsis japonica ethanol extract suppresses migration and invasion in human MDA-MB-231 breast cancer cells. Molecular medicine reports. 2015, 11(5), 3722-3728. https://doi.org/10.3892/mmr.2015.3179

ONG, M.S., et al. Cytoskeletal Proteins in Cancer and Intracellular Stress: A Therapeutic Perspective. Cancer (Basel). 2020, 12(1), 238.

https://doi.org/10.3390/cancers12010238

NETO, J.A.R., et al. Using the plants of Brazilian Cerrado for wound healing: From traditional use to scientific approach. Journal of Ethnopharmacology. 2020, 1(1), 112547. https://doi.org/10.1016/j.jep.2020.112547

RIBEIRO, R.I.M.A., et al. Inibição de metaloproteinases por extratos aquosos de Aloe vera, Annona muricata e chá preto. Bioscience Journal. 2010, 26(1), 121-127.

RUNDHAUG, J.E. Matrix metalloproteinases and angiogenesis. Journal of Cellular and Molecular Medicine. 2005, 9(2), $267-285$. https://doi.org/10.1111/j.1582-4934.2005.tb00355.x

SANTOS, K.M., NUNES, D.A.F., GOMES, I.N.F. and RIBEIRO, R.I.M.A. Inhibition of gelatinase activity of MMP-2 and MMP-9 by extracts of Bauhinia ungulata L. Bioscience Journal. 2015, 31(2), 584-590. https://doi.org/10.14393/BJ-v31n2a2015-23477

SANTOS, K.M., et al. ID7 Isolated from Bauhinia variegata Stem Inhibits Tumor Progression and Metastatic Mechanisms of Triple Negative Breast Cancer in Vivo: ID7 fraction from Bauhinia variegata Inhibits Triple Negative Breast Cancer. Journal of Pharmacy and Pharmacology. 2019, 7(1), 368-384. https://doi.org/10.17265/2328-2150/2019.07.003

SLEEMAN, J.P., et al. Concepts of metastasis in flux: the stromal progression model. Seminars in Cancer Biology. 2012, 22(3), 174-186. https://doi.org/10.1016/j.semcancer.2012.02.007

SORENSON, C.M., BARRY, M.A. and EASTMAN, A. Analysis of events associated with cell cycle arrest at G2 phase and cell death induced by cisplatin. Journal of the National Cancer Institute. 1990, 82(9), 749-755. https://doi.org/10.1093/inci/82.9.749

SOUZA-MOREIRA, T.M., FERNANDES, G.M.Q. and PIETRO, R.C. Stryphnodendron Species Known as "Barbatimão": A Comprehensive Report. Molecules. 2018, 23(4), 910-935. https://doi.org/10.3390/molecules23040910

WANG, Z., et al. Paeoniflorin inhibits migration and invasion of human glioblastoma cells via suppression transforming growth factor $\beta$-induced epithelial-mesenchymal transition. Neurochemical Research. 2018, 43(3), 760-774. https://doi.org/10.1007/s11064-018-2478-y

Received: 31 August 2019 | Accepted: 16 April 2019 | Published: 13 October 2021

This is an Open Access article distributed under the terms of the Creative Commons Attribution License, which permits unrestricted use, distribution, and reproduction in any medium, provided the original work is properly cited. 